\title{
Effect of hot-air drying temperature on nutritional components and rehydration rate of sweetpotato leaves
}

\author{
Da-Woon Jeong ${ }^{1}$, Yang-Kyun Park ${ }^{1}$, Sang-Sik Nam ${ }^{2}$, Seon-Kyeong Han ${ }^{2 *}$ \\ ${ }^{1}$ Department of Food Science and Technology, Mokpo National University, Muan 58554, Korea \\ ${ }^{2}$ Bioenergy Crop Research Institute, National Institute of Crop Science, \\ Rural Development Administration, Muan 55365, Korea
}

\section{열풍건조 온도에 따른 고구마 잎의 영양성분 및 수화복원성 변화

\author{
정다운 ${ }^{1} \cdot$ 박양균 $^{1} \cdot$ 남상식 $^{2} \cdot$ 한선경 $^{2 *}$ \\ ${ }^{1}$ 목포대학교 공과대학 식품공학과, ${ }^{2}$ 농촌진흥청 국립식량과학원 바이오에너지작물연구소
}

\begin{abstract}
The purpose of the present study is to provide preliminary data for turning sweetpotato leaves into dehydrated vegetables. To achieve this goal, we have gone through the process of hot-air drying the leaves of sweetpotato that are usually thrown away and examined the drying speed and rehydration resilience, then made a comparative analysis of the general ingredients, lutein, $\beta$-carotene and chromaticity. The drying speed reached the peak at a temperature of $70^{\circ} \mathrm{C}$. As for other general ingredients, there was no significant difference according to temperature. The content of lutein, which is a functional ingredient, was large in Shinmi with $171.59 \mu \mathrm{g} / \mathrm{g}$ at a temperature of $40^{\circ} \mathrm{C}$; small in Hayanmi with $73.75 \mu \mathrm{g} / \mathrm{g}$ at a temperature of $70^{\circ} \mathrm{C}$. The content of $\beta$-carotene was large in Shinmi with $379.59 \mu \mathrm{g} / \mathrm{g}$ at a temperature of $40^{\circ} \mathrm{C}$; small in Hayanmi with $170.78 \mu \mathrm{g} / \mathrm{g}$ at a temperature of $70^{\circ} \mathrm{C}$. The content of functional materials was the largest at a temperature of $40^{\circ} \mathrm{C}$, and decreased in the order of temperatures at $50^{\circ} \mathrm{C}, 60^{\circ} \mathrm{C}$, and $70^{\circ} \mathrm{C}$. As for rehydration stability, rehydration rate in both Shinmi and Hayanmi was the highest at a temperature of $40{ }^{\circ} \mathrm{C}$ with $233.93 \%$ and $223.47 \%$ respectively. To summarize, the quality of dried sweet potato leaf was more affected by temperature than by drying time, and low temperature drying resulted in better product value.
\end{abstract}

Key words : sweetpotato leaves, rehydration rate, lutein, $\beta$-carotene

\section{서 론}

고구마(Ipomoea batatas L.)는 열대와 온대지역에 걸쳐 광범위하게 재배되고 있으며 세계적으로 매우 중요한 식량 작물로 여겨지고 있다. 특히 환경적응성이 강하고 뿌리, 줄기, 잎을 모두 섭취할 수 있기 때문에 21세기의 식량, 에너지, 환경 문제를 동시에 해결해 줄 수 있는 작물로 많은

*Corresponding author. E-mail : skhan92@korea.kr Phone : 82-61-450-0120, Fax : 82-61-453-0085

Received 13 May 2015; Revised 29 June 2015; Accepted 14 July 2015

Copyright (c) The Korean Society of Food Preservation. All rights reserved.
관심을 받고있다(1,2). 고구마는 우리나라에서도 예로부터 쌀이나 다른 곡식을 대신하는 구황식물로 널리 재배되어 식용으로 이용 되었으나 쌀의 자급이 이루어지면서 재배량 이 감소하다가, 2000년대 들어 건강식품으로 알려지면서 (3-5) 다양한 음식의 부재료로 그 활용의 폭이 점차 넓어져 가면서 전국적으로 재배면적이 증가하였다(6).

미국 나사(NASA)에서도 기후 및 생태계의 변화, 환경의 오염 등 지구의 위기와 함께 미래 우주시대의 모델작물로 고구마를 선정하여 advanced life support system(ALSS)에 서 고구마 지상부의 이용성 증대에 관한연구를 수행하였다 (7). 고구마 잎과 잎자루는 아프리카와 중국, 일본 등지에서 채소로 이용하고 있으며, 다량의 단백질을 함유하고 있어 동물의 단백질 급원으로의 가능성이 제기되기도 하였다 
$(8,9)$. 또한 고구마는 품종과 재배시기에 관계없이 잎에는 항산화기능, 항균작용, 항고혈압작용 및 간보호 기능과 같 은 생리활성이 있음이 보고되었으며(10), Islam 등(11)은 고구마 잎과 잎자루의 항산화 활성을 다른 채소류들과 비교 한 결과 tocopherols과 butylated hydroxytoluene(BHT)보다 높았고 콩나물이나 들깨 잎, 시금치에 비해서도 높았다고 보고하였다. 또한 일본에서는 고구마 잎을 기능성 채소로 활용하기 위하여 영양성분을 증가시킨 다양한 품종이 개발 되었고 고구마 잎을 활용한 기능성 차 개발에 대한 연구가 진행되었다(12). 더불어 천연 색소원으로 주목 받음과 더불 어 건강식품으로서도 많은 관심을 끌고 있으며(13), 고구마 는 뿌리를 비롯해 잎과 잎자루 등 식물체 전체를 식용할 수 있으며, 고구마에는 덩이뿌리나 잎, 잎자루, 줄기에 폴리 페놀 화합물이 많이 존재하기 때문에 해외에서는 고구마의 덩이뿌리뿐만 아니라 잎이나 잎자루 그리고 줄기를 건조한 후 분말로 제조하여 식품의 제조에 이용되고 있다(14).

국내에서는 고구마의 지상부인 줄기와 잎은 주로 뿌리를 목적으로 재배되는 과정에서 극히 일부분만 이용되고 있는 실정이며, 줄기는 주로 김치를 담거나 데쳐서 나물로 먹고 잎은 찌거나 데쳐서 쌈이나 나물로 먹는다. 고구마 잎은 연중 여러 번에 걸쳐 수확을 할 수 있는 이점이 있기도 하다. 그럼에도 불구하고 고구마 뿌리만큼 잎에 대한 연구 는 미비한 실정이다. 따라서 본 연구에서는 국내에서 잘 이용되지 않고 버려지고 있는 고구마의 잎을 각기 다른 온도에서 열풍건조하여 이들의 건조속도와 수화복원력을 조사하고, 일반성분, lutein 과 $\beta$-carotene 및 색도 등을 분석 비교 검토하여 고구마 잎의 건조 채소화를 위한 기초자료를 제공하고자 하였다.

\section{재료 및 방법}

\section{재 료}

본 실험에 사용한 고구마는 농촌진흥청에서 육성한 품종 으로 잎자루용으로 많이 이용되는 품종 ‘신미'와 보라색을 띄고 있는 '하얀미'를 사용하였다. 농촌진흥청 국립식량과 학원 바이오 에너지작물연구소의 비닐하우스 육묘상에 2014년 3월 중순에 파종하고 표준재배법으로 재배하여 8월 에 수확하여 시료로 사용하였다.

\section{건조채소의 제조}

채취한 고구마 잎은 깨끗이 세척하여 이물질을 제거하고 $40^{\circ} \mathrm{C}, 50^{\circ} \mathrm{C}, 60^{\circ} \mathrm{C}, 70^{\circ} \mathrm{C}$ 의 풍속 $1 \mathrm{~m} / \mathrm{sec}$ 인 drying oven (DS-541, Kett Engineering, Tokyo, Japan)을 사용하여 충분 히 건조한 후 분쇄기(MCH-309, Dongyangmagic, Seoul, $\mathrm{Korea}$ )를 이용하여 분쇄하고 $-20^{\circ} \mathrm{C}$ 의 냉동고에 보관하면서 시료로 이용하였다.
건조속도에 대한 온도의 영향을 조사하기 위하여 $40^{\circ} \mathrm{C}$, $50^{\circ} \mathrm{C}, 60^{\circ} \mathrm{C}, 70^{\circ} \mathrm{C}$ 의 건조기에 시료 $12.5 \mathrm{~g}$ 를 $3 \mathrm{~cm}$ 길이로 균일하게 자른 후 알루미늄 용기에 담아 건조시키면서 10 분 간격으로 무게 변화를 조사하였다.

\section{일반성분 분석}

일반성분은 $\mathrm{AOAC}$ 방법(14)에 준하여 분석하였다. 수분 함량은 수분측정기(FD-720, Kett Engineering, Tokyo, $\mathrm{Japan}$ )를 이용하여 측정하고, 회분함량은 $550^{\circ} \mathrm{C}$ 에서 직접 회화법으로 분석하였다. 조단백질 함량과 탄수화물 함량은 원소분석기(vario max cube, Elementar Analysensysteme $\mathrm{GmbH}, \mathrm{Hanau}, \mathrm{Germany)}$ 를 이용하여 분석하였다. 조지방 함량은 지방자동분석기(Soxtec 2050, Foss, Denmark) 이용 하여 분석하였다.

\section{Lutein 과 $\beta$-carotene 함량 분석}

Lutein 과 $\beta$-carotene 함량 분석은 $\operatorname{Li}(15)$ 의 방법을 이용하 였다. 건조시료 $1 \mathrm{~g}$ 을 $10 \mathrm{~mL}$ acetone(containing $0.1 \% \mathrm{BHT}$ ) 가해 sonicator에서 10 분 추출 후, 원심분리기(Union $32 \mathrm{R}$ Plus, Hanil science industrial, Seoul, Korea) 3,000 rpm 조건 에서 15 분간 원심분리를 하여 상등액을 3 회 걸쳐 추출 후 $35^{\circ} \mathrm{C}$ 에서 농축 하였다. 농축한 추출물에 $20 \mathrm{~mL}$ ether (containing $0.1 \% \mathrm{BHT}$ )와 $20 \mathrm{~mL} \mathrm{KOH}(10 \%$ methanolic) 가 해 $4^{\circ} \mathrm{C}$ 어두운 곳에서 3 시간 동안 비누화 반응을 시켰다. 비누화 반응 후 $20 \mathrm{~mL} \mathrm{NaCl}(10 \% \mathrm{w} / \mathrm{v})$ 가한 후 원심분리하 여 상등액은 버리고 하등액을 추출 2 회 반복한 후 이 추출물 에 적당량 $\mathrm{Na}_{2} \mathrm{SO}_{4}$ 를 가해 농축하였다. 농축 후 $5 \mathrm{~mL}$ methanol/ethyl acetate( $1: 1$, containing $0.1 \% \mathrm{BHT}$ )를 가해 추 출 후 $0.20 \mu \mathrm{m}$ PVDF membrane filter로 여과 후 UPLC (ACQuityuplc, waters, USA)로 분석하였다. Column은 ACQuity UPLC HSS $\mathrm{C}_{18}(2.1 \times 100 \mathrm{~mm}, 1.8 \mu \mathrm{m}, \mathrm{USA})$ 을 사용 하였고, 검출기는 $\mathrm{UV}(450 \mathrm{~nm})$, 이동상은 acetone-water를 사용하였으며, 유속 $0.2 \mathrm{~mL} / \mathrm{min}$ 으로 시료 주입량은 $5 \mu \mathrm{L}$ 로 하였다.

\section{색도 측정}

색도의 측정 은 색차계(CM-3500d, Konica Minolta, Tokyo, Japan)를 사용하여 건조조건에 따라 L값(lightness), a값 (redness) 및 b값(yellowness)을 측정하였고, 3회 반복 측정 하여 평균값으로 나타내었다. 전반적인 색차 $\triangle \mathrm{E}$ 아래 식으 로 나타내었다(16). 이때 standard plate의 $\mathrm{L}, \mathrm{a}, \mathrm{b}$ 값은 각각 $97.21,-0.02,1.95$ 이었다.

$$
\Delta \mathrm{E}=\sqrt{\Delta L^{2}+\Delta a^{2}+\Delta b^{2}}
$$

$\triangle \mathrm{L}$ : Difference of lightness

$\triangle \mathrm{a}:$ Difference of redness/greenness

$\Delta \mathrm{b}:$ Difference of yellowness/bluness 


\section{수화복원성}

상기 전처리 및 건조 방법에 따라 제조된 끝순 건채소의 재수화율(rehydration ratio)은 시료 $100 \mathrm{~g}$ 을 $30^{\circ} \mathrm{C}$ 의 water bath에 침지한 다음 2 시간 후 꺼내어 키친 타올로 시료의 표면수를 제거하고 무게를 측정하였으며, 수화복원성은 다 음 식에 의하여 계산하였다.

$$
\text { 수화복원성 }(\%)=\frac{\text { 재수화후시료무게 }- \text { 재수화전시료무게 }}{\text { 재수화전 시료무게 }} \times 100
$$

\section{결과 및 고찰}

\section{생엽의 일반성분}

고구마 생엽의 일반성분을 분석한 결과는 Table 1 과 같 다. 수분 함량은 신미 $88.46 \%$, 하얀미 $87.55 \%$ 로 나타났으 며, 조단백 함량은 신미 $4.80 \%$, 하얀미 $5.14 \%$ 로 나타났다. 탄수화물 함량은 신미 $4.22 \%$, 하얀미 $4.58 \%$ 로 차이는 거의 없는 것으로 보인다. 조회분 함량에서는 신미 $1.73 \%$, 하얀 미 $2.55 \%$ 로 하얀미가 많게 나왔다. 이 결과는 식품성분표 (17)의 고구마 생잎의 분석결과와 분석항목 간에 큰 차이가 없었다.

\section{건조채소의 제조}

고구마 잎의 건조 특성을 측정하기 위해 $12.5 \mathrm{~g}$ 을 건조기 에서 건조한 결과는 Fig. 1 과 같다. 최종수분함량이 6 8\% 에 도달하는 시간은 $70^{\circ} \mathrm{C}$ 에서 신미는 130 분, 하얀미는 110 분, $60^{\circ} \mathrm{C}$ 에서는 신미 190 분, 하얀미 190 분, $50^{\circ} \mathrm{C}$ 에서는 신미 330 분, 하얀미 320 분, $40^{\circ} \mathrm{C}$ 에서 신미 460 분, 하얀미 470 분 이었다. 신미와 하인미 두 품종 간의 차이는 있었으나 대체 로 $70^{\circ} \mathrm{C}$ 에서 건조 시간이 빨랐으며, $40^{\circ} \mathrm{C}$ 에서 건조 시간이 많이 소요되었다. Shinohara와 Wada(18)는 감자 및 고구마 의 건조 실험에서 두께 및 상대습도가 일정한 경우 $50 \sim 90^{\circ} \mathrm{C}$ 의 공기에서는 온도가 높을수록 건조속도가 증가한다고 보고하였다. 본 실험에서 조건별 건조온도가 건조속도에 큰 영향을 미친다는 것과 유사한 경향을 나타내어 $70^{\circ} \mathrm{C}$ 에서 건조 속도가 가장 빠르며, $60^{\circ} \mathrm{C}, 50^{\circ} \mathrm{C}, 40^{\circ} \mathrm{C}$ 순서로 많은 시간이 소요되었다. 따라서 건조속도가 빠른 $70^{\circ} \mathrm{C}$ 가 가장 적합한 것으로 보인다.
(A)

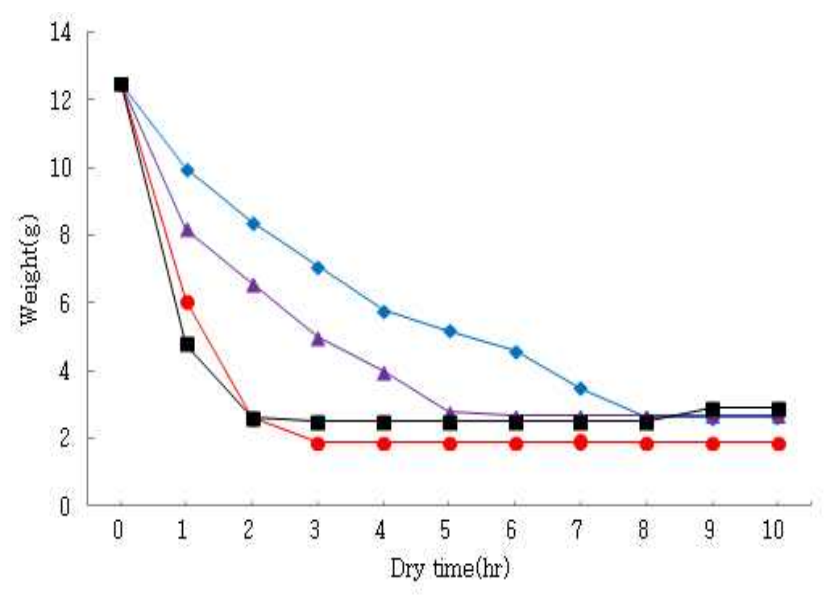

(B)

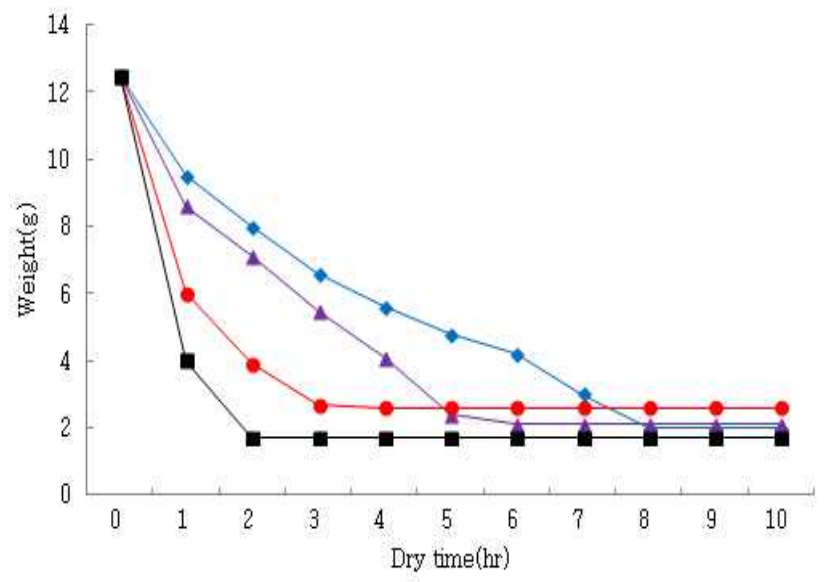

Fig. 1. Drying curves of sweet potato leaves at various dry temperatures.

A, Shinmi; B, Hayanmi. $\square, 40^{\circ} \mathrm{C} ; 50^{\circ} \mathrm{C} ; \boldsymbol{\Delta}, 60^{\circ} \mathrm{C} ; 70^{\circ} \mathrm{C}$.

\section{건조 잎의 일반성분}

고구마 잎의 열풍건조 온도에 따른 일반성분 분석을 한 결과는 Table 2 와 같다. 수분함량은 생엽이 $80 \%$ 대였으나 건조 후에는 6 8\%로 감소하였다. 조단백질 함량은 생엽에 서 4 5\% 였으나 건엽건에서는 신미가 $40^{\circ} \mathrm{C}$ 에서 $32.72 \%$ 로 가장 높았으며, 하얀미의 경우 $60^{\circ} \mathrm{C}$ 에서 $32.00 \%$ 로 많았다. 조지방 함량은 건엽에서 $40^{\circ} \mathrm{C}$ 와 $50^{\circ} \mathrm{C}$ 에서 $2 \%, 60^{\circ} \mathrm{C}$ 와 $70^{\circ} \mathrm{C}$ 에서 $3 \%$ 대로 품종별 온도별 차이는 거의 없었다. 탄수화물 함량은 생엽에서 $4 \%$ 로 측정되었는데 건엽에서는 이에 10

Table 1. Approximate compositions of sweet potato leaves

(unit : \%)

\begin{tabular}{cccccc}
\hline Cultivars & Moisture & Crude protein & Crude lipid & Carbohydrate & Crude ash \\
\hline Shinmi & $88.46 \pm 0.67^{1 \mathrm{la2})}$ & $4.80 \pm 0.21^{\mathrm{a}}$ & - & $4.22 \pm 0.49^{\mathrm{a}}$ & $1.73 \pm 0.13^{\mathrm{b}}$ \\
Hayanmi & $87.55 \pm 1.86^{\mathrm{a}}$ & $5.14 \pm 0.39^{\mathrm{a}}$ & - & $4.58 \pm 0.19^{\mathrm{a}}$ & $2.55 \pm 0.38^{\mathrm{a}}$ \\
\hline
\end{tabular}

${ }^{1)}$ Each value expressed as the mean \pm standard deviation $(\mathrm{n}=3)$.

${ }^{2)}$ Means in the same column with the different are significantly different $(\mathrm{p}<0.05)$ by Duncan's multiple range test. 
배에 달하는 함량이었다. 신미는 $40^{\circ} \mathrm{C}$ 와 $50^{\circ} \mathrm{C}$ 에서 $40 \%$ 정 도였으며, $60^{\circ} \mathrm{C}, 70^{\circ} \mathrm{C}$ 에서는 $41 \sim 42 \%$ 로 높았으며, 하얀미에 서는 $40^{\circ} \mathrm{C}, 50^{\circ} \mathrm{C}$ 에서 $41 \%$ 였으며, $60^{\circ} \mathrm{C}, 70^{\circ} \mathrm{C}$ 에서는 $43 \%$ 로 높았으나 유의적인 차이는 없었다. 조회분 함량은 생엽에 서 1 2\% 였으며, 건엽에서는 신미가 $40^{\circ} \mathrm{C}$ 에서 13.14 로 많았 으며, 하얀미 $70^{\circ} \mathrm{C}$ 에서 10.98 로 적었다. $\mathrm{Li}$ 등(19)은 14 품종 의 고구마 잎의 조단백질과 조회분 함량을 분석한 결과 조단백질 함량은 15.57 20.34\%로 보고하였는데, 본 실험에 서는 이보다 더 높게 나왔으며, 조회분 함량은 9.81 14.91\% 로 보고하였는데 비슷한 경향을 보였다. 이러한 성분차이 의 주요원인은 품종에 따른 유전적인 요인이라고 하였다 (20). 본 연구에서는 열풍건조 온도에 따른 일반 성분의 차이는 거의 없었다.
Table 3. Lutein and $\beta$-carotene contents of sweet potato leaves at various dry temperatures

\begin{tabular}{|c|c|c|c|}
\hline & & & it : $\mu \mathrm{g} / \mathrm{g}$, dry basis \\
\hline Cultivars & $\begin{array}{c}\text { Temp. } \\
\left({ }^{\circ} \mathrm{C}\right)\end{array}$ & Lutein & B-carotene \\
\hline \multirow{4}{*}{ Shinmi } & 40 & $171.59 \pm 6.17^{1) 22}$ & $379.59 \pm 1.29^{\mathrm{a}}$ \\
\hline & 50 & $148.13 \pm 5.95^{\mathrm{b}}$ & $326.58 \pm 6.12^{\mathrm{bc}}$ \\
\hline & 60 & $92.19 \pm 7.69^{c}$ & $266.44 \pm 9.23^{\mathrm{d}}$ \\
\hline & 70 & $89.24 \pm 3.60^{c}$ & $263.64 \pm 8.09^{\mathrm{d}}$ \\
\hline \multirow{4}{*}{ Hayanmi } & 40 & $147.03 \pm 1.65^{b}$ & $330.09 \pm 3.69^{b}$ \\
\hline & 50 & $141.15 \pm 6.20^{b}$ & $310.52 \pm 1.16^{c}$ \\
\hline & 60 & $92.80 \pm 9.56^{\mathrm{C}}$ & $287.90 \pm 5.34^{d}$ \\
\hline & 70 & $73.75 \pm 4.85^{\mathrm{d}}$ & $170.78 \pm 1.16^{\mathrm{e}}$ \\
\hline
\end{tabular}

${ }^{1)}$ Each value expressed as the mean \pm standard deviation $(n=3)$

${ }^{2}$ Means in the same column with the different are significantly different $(p<0.05)$ by Duncan's multiple range test.

Table 2. Approximate compositions of sweet potato leaves at various dry temperatures

(unit : \%)

\begin{tabular}{ccccccc}
\hline Cultivars & $\begin{array}{c}\text { Temp. } \\
\left({ }^{\circ} \mathrm{C}\right)\end{array}$ & Moisture & Crude protein & Crude lipid & Carbohydrate & Crude ash \\
\hline \multirow{6}{*}{ Shinmi } & 40 & $6.63 \pm 0.82^{1 \mathrm{1b} 2)}$ & $32.72 \pm 0.12^{\mathrm{a}}$ & $2.35 \pm 0.40^{\mathrm{bc}}$ & $40.39 \pm 0.03^{\mathrm{b}}$ & $13.14 \pm 0.21^{\mathrm{a}}$ \\
& 50 & $7.40 \pm 0.4^{\mathrm{ab}}$ & $32.67 \pm 0.38^{\mathrm{a}}$ & $2.46 \pm 0.18^{\mathrm{bc}}$ & $40.80 \pm 0.18^{\mathrm{b}}$ & $12.64 \pm 0.09^{\mathrm{b}}$ \\
& 60 & $7.09 \pm 0.27^{\mathrm{b}}$ & $32.17 \pm 0.08^{\mathrm{b}}$ & $3.37 \pm 0.15^{\mathrm{a}}$ & $42.64 \pm 0.25^{\mathrm{a}}$ & $12.76 \pm 0.13^{\mathrm{ab}}$ \\
& 70 & $7.95 \pm 0.12^{\mathrm{a}}$ & $29.37 \pm 0.28$ & $3.58 \pm 0.24^{\mathrm{a}}$ & $41.76 \pm 1.53^{\mathrm{ab}}$ & $12.11 \pm 0.10^{\mathrm{c}}$ \\
\hline \multirow{3}{*}{ Hayanmi } & 40 & $6.67 \pm 0.79^{\mathrm{b}}$ & $30.23 \pm 0.14^{\mathrm{f}}$ & $2.47 \pm 0.02^{\mathrm{b}}$ & $41.13 \pm 0.03^{\mathrm{b}}$ & $11.14 \pm 0.11^{\mathrm{ef}}$ \\
& 50 & $7.48 \pm 0.67^{\mathrm{ab}}$ & $31.58 \pm 0.23^{\mathrm{d}}$ & $2.17 \pm 0.11^{\mathrm{c}}$ & $41.52 \pm 0.94^{\mathrm{a}}$ & $11.43 \pm 0.01^{\mathrm{d}}$ \\
& 60 & $6.34 \pm 0.84^{\mathrm{b}}$ & $32.00 \pm 0.05^{\mathrm{c}}$ & $3.49 \pm 0.12^{\mathrm{a}}$ & $43.03 \pm 0.17^{\mathrm{a}}$ & $11.27 \pm 0.09^{\mathrm{e}}$ \\
& 70 & $7.43 \pm 0.50^{\mathrm{ab}}$ & $30.82 \pm 0.22^{\mathrm{e}}$ & $3.51 \pm 0.57^{\mathrm{a}}$ & $43.14 \pm 0.42^{\mathrm{a}}$ & $10.98 \pm 0.16^{\mathrm{f}}$ \\
\hline
\end{tabular}

${ }^{1)}$ Each value expressed as the mean \pm standard deviation $(n=3)$.

${ }^{2)}$ Means in the same column with the different are significantly different $(\mathrm{p}<0.05)$ by Duncan's multiple range test.

\section{Lutein 과 $\beta$-carotene 함량 분석}

건조 온도에 따른 고구마 잎의 lutein, $\beta$-carotene 함량은 Table 3 과 같다. lutein 함량에서 신미가 $40^{\circ} \mathrm{C}$ 에서 171.59 $\mu \mathrm{g} / \mathrm{g}$, 하얀미 $40^{\circ} \mathrm{C}$ 에서 $147.03 \mu \mathrm{g} / \mathrm{g}$ 많았으며, 신미 $70^{\circ} \mathrm{C}$ 에서 $89.24 \mu \mathrm{g} / \mathrm{g}$, 하얀미 $70^{\circ} \mathrm{C}$ 에서 $73.75 \mu \mathrm{g} / \mathrm{g}$ 로 적었다. $\beta$ -carotene 함량에서 신미가 $40^{\circ} \mathrm{C}$ 에서 $379.59 \mu \mathrm{g} / \mathrm{g}$, 하얀미 $40^{\circ} \mathrm{C}$ 에서 $330.09 \mu \mathrm{g} / \mathrm{g}$ 로 많았으며, 신미 $70^{\circ} \mathrm{C}$ 에서 263.64 $\mu \mathrm{g} / \mathrm{g}$, 하얀미 $70^{\circ} \mathrm{C}$ 에서 $170.78 \mu \mathrm{g} / \mathrm{g}$ 로 적었다. $\mathrm{Li}(15)$ 의 연구 에 따르면 $50^{\circ} \mathrm{C}$ 에서 열풍 건조한 14 품종의 고구마 잎에서 lutein, $\beta$-carotene 함량을 측정한 결과 lutein 함량은 $190.1 \sim 288.5 \mu \mathrm{g} / \mathrm{g}, \quad \beta$-carotene 함량은 352.1 520.1 $\mu \mathrm{g} / \mathrm{g}$ 로 보고하였다. 본 실험에서 결과는 이와 비교하였을 때 다소 낮은 값을 나타내지만 품종간의 차이가 있기 때문이라고 생각된다. 본 연구에서는 건조 온도가 높아질수록 lutein, $\beta$-carotene 함량은 감소하는 경향을 보였다. 즉 lutein, $\beta$ -carotene 함량이 높은 온도인 $40^{\circ} \mathrm{C}$ 가 가장 적당하다고 판단 된다.

\section{색도 측정}

식품의 외부색택은 외관상의 품질을 판정하는데 중요한 요인 중의 하나로, 건조 후 고구마 잎의 색도를 색차계를 이용하여 L값, $\mathrm{a}$ 값, $\mathrm{b}$ 값을 측정 비교한 결과 Table 4와 같다. $\mathrm{L}$ 값은 신미 $40^{\circ} \mathrm{C}$ 에서 38.18 , 하얀미 $40^{\circ} \mathrm{C}$ 에서 34.39 로 높았 다. 품종별로 차이가 있긴 하였지만 건조 온도가 낮을수록 많았으며, 이러한 결과는 증절간 호박고구마의 냉풍건조과 정 중 물성의 변화에서 건조가 진행될수록 $\mathrm{L}$ 값이 대체로 감소하는 경향을 보인 것으로 보고한 Shin 등(21)의 결과와 유사하였다. a값은 신미 $70^{\circ} \mathrm{C}$ 에서 -3.04 , 하얀미 $70^{\circ} \mathrm{C}-0.16$ 으로 높았다. 품종 간의 차이가 있긴 하였지만 건조 온도가 높을수록 증가하는 경향이었다. a값의 음의 값을 갖는 이유 는 초기 측정값이 red보다 green 쪽으로 나타나기 때문이다. $\mathrm{b}$ 값은 신미 $40^{\circ} \mathrm{C}$ 에서 25.61 , 하얀미 $40^{\circ} \mathrm{C}$ 에서 38.47 로 높았 다. 품종별로 차이가 있긴 하였지만 건조 온도가 낮을 수록 값이 증가하였다. 이는 열풍 건조 무청의 품질특성에서 녹 색도를 나타내는 $-\mathrm{a}$ 값은 건조온도가 증가할수록 감소하는 경향을 보인 것으로 보고한 $\mathrm{Ku}$ 등(22)의 결과와 유사하였 
다. $\triangle \mathrm{E}$ 는 건조온도에 따라 육안으로 색의 차이를 확실하 게 구별할 수 있는 높은 값이었다. 품종별로 차이는 있었지 만 온도가 낮을수록 $\Delta \mathrm{E}$ 값이 감소하였다. 따라서 건조 온도가 낮을수록 고유의 색을 보다 더 유지하는 건조 온도 가 높을수록 색이 보다 더 많이 변한 것을 알 수 있었으며 $40^{\circ} \mathrm{C}$ 가 가장 적당한 것으로 판단된다.

\section{수화복원성}

건조채소의 복원성은 건조채소의 중요한 품질 특성중의 하나이다. 건조식품의 재수화에 의한 복원은 단순히 건조 의 역반응은 아니다. 그 이유는 건조에 의해서 어떤 변화는 비가역적으로 일어날 수 있으며, 특히 손상된 조직들은 원 상태로 복구될 수 없으며 조직 내의 용질들이 용출되어
나가기 때문이다. 따라서 건조채소의 수화복원성은 건조 온도에 영향을 받게 된다. 건조온도에 따른 건조채소의 수 화복원성을 측정한 결과는 Table 5 와 같다. 신미 $40^{\circ} \mathrm{C}$ 에서 $233.93 \%$, 하얀미 $40^{\circ} \mathrm{C}$ 에서 $223.47 \%$ 로 높았으며, 신미 $70^{\circ} \mathrm{C}$ 에서 $176.91 \%$, 하얀미 $70^{\circ} \mathrm{C}$ 에서 $176.91 \%$ 로 낮았다. 품종 간에 차이는 있지만 대체적으로 건조 온도가 낮을수록 높은 수화복원성을 보였다. 이는 건조 방법이 건조 채소류 의 품질에 미치는 영향에서 열풍 건조한 시료들 중에서 는 작은 온도에서 건조한 채소의 수화복원성이 높았다고 보고한 Hwang과 Rhim(23)의 결과와 유사하였다. 따라서 건조할 때 열에 의한 손상을 덜 받는 방법을 적용하는 것이 높은 수화복원성을 나타냄을 알 수 있었다. 즉 본 연구에서 는 $40^{\circ} \mathrm{C}$ 에서 건조하는 방법이 가장 적절한 것으로 판단된다.

Table 4. $\mathrm{L}, \mathrm{a}, \mathrm{b}$ values and $\Delta \mathrm{E}$ of sweet potato leaves at various dry temperatures

\begin{tabular}{|c|c|c|c|c|c|}
\hline \multirow{2}{*}{ Cultivar } & \multirow{2}{*}{$\begin{array}{c}\text { Temp. } \\
\left({ }^{\circ} \mathrm{C}\right)\end{array}$} & \multicolumn{4}{|c|}{ Sweet potato leaves } \\
\hline & & $\mathrm{L}$ & $\mathrm{a}$ & $\mathrm{b}$ & $\triangle E$ \\
\hline \multirow{5}{*}{ Shinmi } & control & $38.18 \pm 1.23^{1 / 22)}$ & $-8.74 \pm 2.77^{c}$ & $25.61 \pm 1.27^{\mathrm{a}}$ & - \\
\hline & 40 & $35.56 \pm 1.50^{\mathrm{a}}$ & $-4.93 \pm 2.58^{b}$ & $15.97 \pm 1.10^{\mathrm{b}}$ & $10.90 \pm 1.66^{b}$ \\
\hline & 50 & $35.28 \pm 2.07^{\mathrm{a}}$ & $-3.92 \pm 1.13^{b}$ & $13.83 \pm 1.01^{\mathrm{bc}}$ & $13.17 \pm 1.12^{b}$ \\
\hline & 60 & $32.91 \pm 2.44^{b c}$ & $-3.24 \pm 2.23^{b}$ & $12.94 \pm 0.68^{c}$ & $14.94 \pm 1.98^{\mathrm{ab}}$ \\
\hline & 70 & $28.85 \pm 1.45^{\mathrm{d}}$ & $-3.04 \pm 0.41^{b}$ & $10.51 \pm 1.87^{c}$ & $18.67 \pm 1.72^{\mathrm{a}}$ \\
\hline \multirow{5}{*}{ Hayanmi } & control & $34.39 \pm 0.84^{b}$ & $-4.97 \pm 2.77^{b}$ & $16.34 \pm 1.42^{b}$ & - \\
\hline & 40 & $29.44 \pm 0.71^{\mathrm{cd}}$ & $-0.72 \pm 0.25^{\mathrm{a}}$ & $6.19 \pm 0.71^{e}$ & $12.08 \pm 0.86^{b}$ \\
\hline & 50 & $29.18 \pm 1.90^{\mathrm{cd}}$ & $-0.44 \pm 1.75^{\mathrm{a}}$ & $5.45 \pm 1.60^{\mathrm{e}}$ & $13.12 \pm 0.87^{b}$ \\
\hline & 60 & $28.50 \pm 0.81^{\mathrm{d}}$ & $-0.18 \pm 1.06^{\mathrm{a}}$ & $5.70 \pm 0.85^{\mathrm{e}}$ & $13.10 \pm 1.18^{b}$ \\
\hline & 70 & $23.23 \pm 2.54^{\mathrm{e}}$ & $-0.16 \pm 1.49^{\mathrm{a}}$ & $7.76 \pm 1.66^{\mathrm{de}}$ & $14.90 \pm 3.21^{\mathrm{ab}}$ \\
\hline
\end{tabular}

${ }^{1)}$ Each value expressed as the mean \pm standard deviation $(\mathrm{n}=3)$

${ }^{2)}$ Means in the same column with the different are significantly different $(p<0.05)$ by Duncan's multiple range test.

Table 5. Moisture contents and rehydration rates of sweet potato leaves at various dry temperatures

(unit : \%)

\begin{tabular}{ccc}
\hline Cultivar & $\begin{array}{c}\text { Temp. } \\
\left({ }^{\circ} \mathrm{C}\right)\end{array}$ & Rehydration rate \\
\hline 40 & $\left.233.93 \pm 6.31^{1) \mathrm{a} 2}\right)$ \\
Shinmi & 50 & $218.04 \pm 3.73^{\mathrm{bc}}$ \\
& 60 & $211.85 \pm 4.61^{\mathrm{c}}$ \\
& 70 & $176.91 \pm 4.63^{\mathrm{e}}$ \\
\hline & 40 & $223.47 \pm 5.26^{\mathrm{ab}}$ \\
& 50 & $185.04 \pm 1.78^{\mathrm{d}}$ \\
& 60 & $169.58 \pm 7.96^{\mathrm{f}}$ \\
& 70 & $176.91 \pm 4.63^{\mathrm{e}}$ \\
\hline
\end{tabular}

${ }^{1)}$ Each value expressed as the mean \pm standard deviation $(\mathrm{n}=3$ ).

${ }^{2}$ Means in the same column with the different are significantly different $(p<0.05)$ by Duncan's multiple range test

\section{요 약}

본 연구에서는 국내에서 잘 이용되지 않는 고구마 잎을 열풍건조하여 이들의 건조속도와 수화복원력을 조사하고, 일반성분, lutein 과 $\beta$-carotene 및 색도 등을 분석 비교 검토 하여 고구마 잎의 건조 채소화를 위한 기초자료를 제공하고 자 하였다. 품종 간의 차이는 있었으나 온도가 높을수록 건조속도가 증가해 $70^{\circ} \mathrm{C}$ 에서 건조속도가 가장 빠르며, 6 $0^{\circ} \mathrm{C}, 50^{\circ} \mathrm{C}, 40^{\circ} \mathrm{C}$ 순서로 건조시간이 많이 소요되었다. 일반 성분은 생엽에서 수분 87 88\%로 많았으나 열풍건조 후 $6 \sim 8 \%$ 이었다. 다른 일반성분은 온도별에 따른 유의적인 차이는 없었다. 기능성 성분인 lutein 함량은 신미 $40^{\circ} \mathrm{C}$ 에서 $171.59 \mu \mathrm{g} / \mathrm{g}$ 많았으며, 하얀미 $70^{\circ} \mathrm{C}$ 에서 $73.75 \mu \mathrm{g} / \mathrm{g}$ 로 적었 다. $\beta$-carotene 함량에서 신미가 $40^{\circ} \mathrm{C}$ 에서 $379.59 \mu \mathrm{g} / \mathrm{g}$ 많고, 하얀미 $70^{\circ} \mathrm{C}$ 에서 $170.78 \mathrm{\mu g} / \mathrm{g}$ 로 적었다. 기능성 물질은 $40^{\circ} \mathrm{C}$ 
에서 가장 많고 $50^{\circ} \mathrm{C}, 60^{\circ} \mathrm{C}, 70^{\circ} \mathrm{C}$ 순서로 함량이 감소되었다. 색도는 생잎과 건잎을 비교하였을 때 신미와 하얀미 모두 $40^{\circ} \mathrm{C}$ 에서 색이 유지되었으며, 수화복원성에서도 신미와 하 얀미 모두 $40^{\circ} \mathrm{C}$ 에서 수화복원율이 각각 $233.93 \%, 223.47 \%$ 로 가장 높았다. 결과적으로 건조 고구마 잎의 품질은 건조 시간보다는 온도 영향이 컸으며 저온건조가 상품적 가치가 있는 것으로 판단되었다.

\section{감사의 글}

본 논문은 농촌진흥청 기관고유사업(과제번호 : PJ008716052015)의 지원에 의해 이루어진 결과의 일부이 며 이에 감사드립니다.

\section{References}

1. Ishida $\mathrm{H}$, Suzuno $\mathrm{H}$, Sugiyama $\mathrm{N}$, Innami $\mathrm{S}$, Tadokoro T, Maekawa A (2000) Nutritive evaluation on chemical components of leaves, stalks and stems of sweet potatoes (Ipomoea batatas poir). Food Chem, 68, 359-367

2. Woo KS, Seo HI, Lee YH, Kim HY, Ko JY, Song SB, Lee JS, Jung KY, Nam MH, Oh IS, Jeong HS (2012) Antioxidant compounds and antioxidant activities of sweet potatoes with cultivated conditions. J Korean Soc Food Sci Nutr, 41, 519-525

3. Huang DJ, Lin CD, Chen HJ, Lin YH (2004) Antioxidant and antiproliferative activities of sweet potato (Ipomoea batata [L.] Lam 'Tainong 57') constituents. Bot Bull Acad Sin, 25, 179-186

4. Islam S (2006) Sweetpotato (Ipomoea banatas L.) leaf : its potential effect on human health and nutrition. $\mathbf{J}$ Food Sci, 71, 13-21

5. Teow CC, Truong VD, McFeeters RF, Thompson RL, Pecota KV, Yencho GC (2007) Antioxidant activities, phenolic and $\beta$-carotene contents of sweet potato genotypes with varying flesh colours. Food Chem, 103, 829-838

6. Park JS, Chung BW, Bae JO, Lee JH, Jung MY, Choi DS (2008) Effects of sweet potato cultivars and koji types on general properties and volatile flavor compounds in sweet potato soju. Korean J Food Sci Technol, 42, 468-474

7. Aurea MA, Fatima B, Collteet J (1997) Nutritional quality of sweet potato greens form green house plants. J Food Compos Anal, 10, 246-253
8. Van AL, Hong TT, Ogle B, Lindverg JE (2005) Utilization of ensiled sweet potato (Ipomoea batatas (L.) Lam.) leaves as a protein supplement in diets for growing pigs. Trop Anim Health Prod, 37, 77-88

9. Bovell-Benjamin AC (2007) Sweet potato : a review of its past, present, and future role in human nutrition. Adv Food Nutr Res, 52, 1-59

10. Lee JS, Shin MJ, Park YK, Ahn YS, Chung MN, Kim HS, Kim JM (2007) Antibacterial and antimutagenic effects of sweetpotato tips extract. Korean J Crop Sci, 52, 303-310

11. Islam MS, Yoshimoto M, Terahara N, Yamakawa O (2002) Anthocyanin compositions in sweet potato (Ipomoea batatas L.) leaves. Biosci Biotechnol Biochem, 66, 2483-2486

12. Ishiguro $\mathrm{K}$, Toyama J, Islam MS, Yoshimoto M, Kumagai T, Kai Y, Nakazawa Y, Yamakawa O (2004) A new sweet potato cultivar for utilization in vegetable greens. Acta Hort, 637, 339-345

13. Yoshimoto M, Okuno S, Yamaguchi M, Yamakawa O (2001) Antimutagenicity of deacylated anthocyanins in purple fleshed sweetpotato. Biosci Biotechnol Biochem, 65, 1652-1655

14. AOAC (1990) Official methods of analysis. 15th ed., Association of official analytical chemists. Washington DC, USA

15. Li Meishan (2013) Physicochemical characteristics and optimization of functional components extraction in sweet potato (Ipomoea batatas L.) leaves and stalks. Chungbuk National University, Korea, 18-19

16. Sapers GM, Douglas FW (1987) Measurement of enzymatic browning at cut surfaces and in juice of raw apple and pear fruits. J Food Sci, 52, 1258-1262

17. Rural Development Administration (2011) Food composition table. National Academy of Agrigulture Science, Korea, 118-119

18. Sinohara H, Wada M (1995) Air drying of sweet potato. Chem Eng, 19, 568-573

19. Meishan L, Jang GY, Lee SH, Woo KS, Sin HM, Kim HS, Lee JS, Jeong HS (2012) Chemical compositions and antioxidant activities of leaves and stalks from different sweet potato cultivars. Korean J Food Sci, 41, 1656-1662

20. Woolfe JA (1992) Sweet potato. Cambridage University Press, New York, NY, USA, p 118-187

21. Shin MY, Lee WY (2011) Optimization of the cold-air-drying condition for a steamed pumpkin 
sweetpotato slab. Korean J Food Preserv, 18, 488-496

22. Ku KH, Lee KA, Kim YL, Lee YW (2006) Quality characteristics of hot-air dried radish (Raphanus sativus L.) leaves. J Korean Soc Food Sci Nutr, 35, 780-785
23. Hwang KT, Rhim JW (1994) Effect of various pretreatments and drying methods on the quality of dried vegetables. Korean J Food Sci, 26, 805-813 